\title{
Effect of diagenesis on pore pressures in fine-grained rocks in the Egersund Basin, Central North Sea
}

\author{
Mohsen Kalani', Mohammad Koochak Zadeh', Jens Jahren', Nazmul Haque Mondol',2 \\ \& Jan Inge Faleide'
}

${ }^{1}$ Department of Geosciences, University of Oslo, Oslo, Norway.

${ }^{2}$ Norwegian Geotechnical Institute (NGI), Oslo, Norway.

E-mail corresponding author (Mohsen Kalani):mohsen.kalani@geo.uio.no,mohsen.kalani@gmail.com

\begin{abstract}
Pore pressure in fine-grained rocks is important with respect to drilling problems such as kicks, blowouts, borehole instability, stuck pipe and lost circulation. In this study, a succession of overpressured, fine-grained, sedimentary rocks located in the Egersund Basin, Central North Sea, was analysed with respect to mineralogical composition, source-rock maturation and log-derived petrophysical properties to highlight the effect of diagenetic processes on the pore pressure. Petrographic and geochemical analyses showed that the overpressure in the study area is largely linked to disequilibrium compaction, illitisation and source-rock maturation shown by log-derived physical properties. Pore-pressure prediction based on the difference of log-derived sonic transit time compared to the normal compaction trend (NCT) of fine-grained rocks can be used to infer the general trends of pore-pressure changes. However, during such pore-pressure prediction (e.g., using Eaton's approach), one should note that with regard to sonic response of the above-mentioned processes, the sonic log-derived, predicted pore pressure in the chemically compacted intervals and organicrich thermally mature successions may show either underestimations or overestimations, respectively.
\end{abstract}

Keywords: overpressure, pore pressure, clay minerals, diagenesis, organic carbon-rich shale, Egersund Basin

Received 16. February / Accepted 29. June / Published online 9. October.

\section{Introduction}

A number of mechanisms have been cited as causes of abnormal pore pressures. These are generally categorised into two main processes: stress-related mechanisms and fluid expansion (Swarbrick \& Osborne, 1998; Swarbrick et al., 2002). In subsiding basins, the overburden load is the main stress which contributes to mechanical compaction of sediments. The mechanical compaction is a function of vertical effective stress which is defined by Terzaghi (1925) as :

$\sigma_{\mathrm{v}}=\sigma_{\mathrm{v}}-\mathrm{p}_{\mathrm{p}}$

where $\sigma_{v}$ is the vertical effective stress, $\sigma_{v}$ is the overburden load (lithostatic or vertical stress) and $p_{p}$ is the pore pressure. By increasing the effective stress, the bulk density of the sediment increases with shrink- age of the pore volume of the sediments. The rate of decreasing pore volume (porosity reduction) is relatively fast at the beginning of mechanical compaction before slowing down when a more rigid frame is formed during deeper burial (e.g., Mondol et al., 2007). This behaviour is particularly pronounced in fine-grained sediments which initially have a very high porosity $(80-90 \%)$ at the surface and lose most of the porosity at relatively shallow depths (Poelchau et al., 1997 and references therein; Mondol et al., 2007). Decreasing the pore volume is directly related to the expulsion of pore fluid. If the rate of pore fluid expulsion is less than what would result from drained stress-induced compaction, the pore pressure will exceed the hydrostatic pressure. Fine-grained, clay-rich sediments can maintain high amounts of bound water due to their large specific surface area and high cation exchange capacity (Henry, 1997; Conin et al., 2011). On the other hand, these sediments have relatively low permeabilities which makes it

Kalani, M., Koochak Zadeh, M., Jahren, J., Mondol, N.H. \& Faleide, J.I. 2015: Effect of diagenesis on pore pressures in fine-grained rocks in the Egersund Basin, Central North Sea. Norwegian Journal of Geology 95, 171-189. http://dx.doi.org/10.17850/njg95-2-03.

(C) Copyright the authors.

This work is licensed under a Creative Commons Attribution 4.0 International License. 
even more difficult to expel the pore fluid out of the pore space during compaction (Mondol et al., 2008a). Thus, mudstones and shales are prone to show overpressure during mechanical compaction. Examples of fluid pressure build-up in shallow buried shales and mudstones can be found in smectite-bearing shales of the Paleogene succession in the North Sea (Thyberg et al., 2000; Mondol et al., 2008a, 2008b; Marcussen et al., 2009; Koochak Zadeh et al., 2014).

With increasing depth and temperatures, chemical diagenesis governs the compaction process and changes rock properties of the fine-grained siliciclastic rocks. Illitisation is the most important diagenetic processes in such rocks, resulting in alteration of smectite and kaolinite to illite and silica cement (microquartz) and water (smectite $+\mathrm{K}^{+}=$illite + silica $+\mathrm{H}_{2} \mathrm{O}$ and kaolinite $+\mathrm{K}^{+}=$illite + silica $+\mathrm{H}_{2} \mathrm{O}$ ) (Boles \& Franks, 1979; Thyberg \& Jahren, 2011). As seen in the equations, the illitisation process involves the release of bound water, whereas the cementation potentially reduces the permeability and prevents excess pore-water expulsion. Within organic-rich mudstone and shale intervals, hydrocarbon generation and/or cracking to lighter hydrocarbons (i.e., oil to gas cracking) can notably increase pore pressure due to the low expulsion rate of hydrocarbons particularly in mud-dominated rocks (Mann, 1994).

Pore pressure prediction has always been a challenge, particularly in fine-grained rocks because no direct pressure measurements are performed within these rocks. Fine-grained successions are important in petroleum exploration and exploitation, since they are the source of the petroleum and also act as cap rocks. Recently, shales have become even more important as unconventional hydrocarbon plays such as shale oil and shale gas (Passey et al., 2010; Hart et al., 2013). Furthermore, fine-grained successions should be treated appropriately during drilling to avoid borehole stability issues.

Several authors have proposed different approaches to estimate pore pressure from well logs and seismic data (Hottmann \& Johnson, 1965; Eaton, 1972, 1975; Bowers, 1995; Sayers et al., 2002; Krushin, 2014). Typically, these approaches are based on considering general compaction trends in measured parameters such as sonic transit time, resistivity and bulk density with depth which are known as normal compaction trends (NCT).

Petrophysical implications of overpressure, however, are different. Pore pressure prediction based on the difference of log-derived sonic transit time or resistivity compared to NCT of shales to estimate the reservoir pressure of a coarse-grained, brine-saturated, shallow layer was developed as early as the1960s (Hottmann \& Johnson, 1965) - Similar techniques were also successfully adapted for shallow, overpressured, fine-grained intervals (Mondol et al., 2008b; Krushin, 2014; Yu \& Hilterman, 2014). Eaton's equation for pore pressure prediction using sonic transit time (Eaton, 1975) has found more interest in the petroleum industry compared to the other approaches. Eaton (1975) suggested empirical equations for estimating pore pressure as a function of log-derived physical properties including sonic compressional transit time:

$\frac{P}{D}=\frac{S}{D}-\left(\frac{S}{D}-\left(\left(\frac{P}{D}\right)\right)\left(\frac{\Delta t_{n}}{\Delta t}\right)^{3}\right.$

where, $\mathrm{P} / \mathrm{D}$ and $\mathrm{S} / \mathrm{D}$ are the formation pore pressure and overburden gradients, respectively. $\Delta \mathrm{t}$ is the measured sonic transit time from the log. $(\mathrm{P} / \mathrm{D})_{\mathrm{n}}$ and $\Delta \mathrm{t}_{\mathrm{n}}$ are also the formation pore pressure and sonic transit time expected in normally pressured conditions as a function of burial depth, respectively.

However, illitisation, kerogen and/or hydrocarbon occurrence result in altered sonic transit time or resistivity responses. Accordingly, during pore pressure estimation using the log response, one should consider the processes responsible for overpressure formation. However, despite the limitations in predicting pore pressure, log-derived petrophysical properties can delineate the overpressured intervals.

In this study, fine-grained overpressured intervals from the Egersund Basin in the Central North Sea were analysed with regard to mineralogical composition, organic carbon content and log-derived petrophysical properties in order to highlight the effect of diagenetic processes on abnormal pore pressure. We start with a brief description of the Egersund Basin and its geological framework. Then, the methodology used for the petrophysical evaluation of well logs, mineralogical composition analyses of drilled cuttings and their SEM imaging is explained. A combination of petrophysical evaluation, mineralogical studies, petrography and geochemical analyses is applied to explain the effects of chemical diagenesis and hydrocarbon generation on building up pore pressure in the fine-grained sediments. With regard to the chemical diagenesis reactions and process of hydrocarbon generation, the applicability of the common pore pressure estimation from sonic velocity data is discussed. We can therefore conclude that velocity-based estimation methods cannot yield even a close estimation of pore pressure in consolidated or organic-rich mudstones and shales.

\section{Study area}

The NW-SE-trending Egersund Basin is a sub-basin of the Central North Sea Province located to the east of the Central Graben between the Stavanger Platform and the Sele and Flekkefjord highs (Fig. 1A). According to Sørensen et al. (1992), two major rift phases (PermianEarly Triassic and Late Jurassic-Early Cretaceous) have governed the major tectonostratigraphic development of the Egersund Basin. The present-day configuration of the basin, however, is largely inherited from the Mesozoic rifting. The basin contains proven petroleum resources (i.e., 


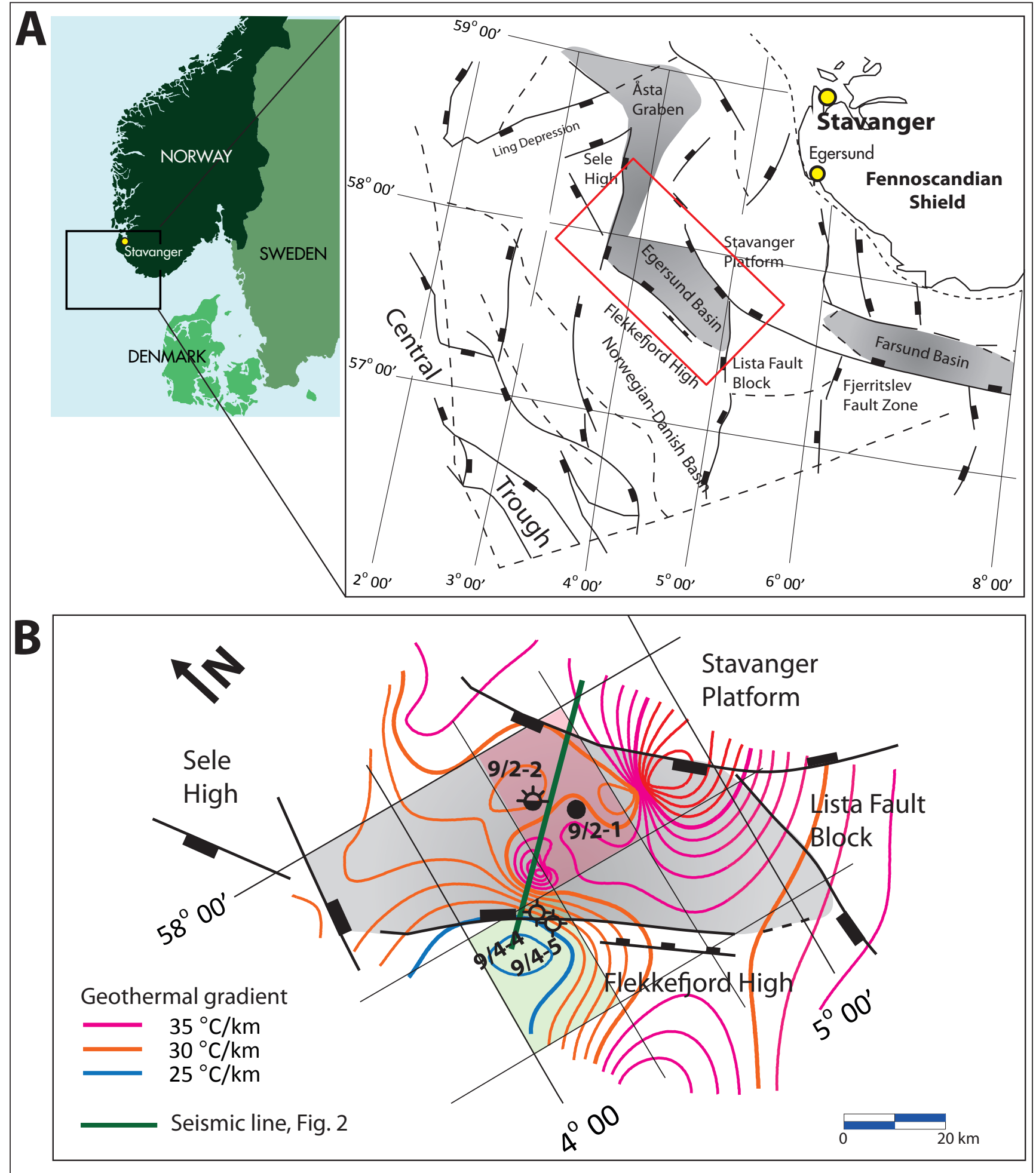

Figure 1. (A) Main structural elements of the Egersund Basin and adjacent areas in the Central North Sea. (B) Location of studied exploration wells and the seismic line in Fig. 2 as well as bottom-hole based geothermal gradients adapted from a regional map of geothermal gradients in the larger Egersund Basin area (modified after Kalani et al., in press; structural base-map adapted from Sørensen \& Tangen, 1995).

Yme Field), which were exploited between 1987 and 2001 (Evans, 2003). In 2001, the field was abandoned since it was then considered as unprofitable. New production at the Yme Field is planned. According to the Norwegian Petroleum Directorate Fact Pages (NPD, 2014), new production from the Yme Field will be carried out mainly assisted by water injection. The fact that only limited petroleum exploration and exploitation currently takes place in the Egersund Basin also makes the structure a well suited area for $\mathrm{CO}_{2}$ storage in the Middle Jurassic Vestland Group reservoir rocks (Halland et al., 2011; Angeli et al., 2013). 
As a part of the regional map of the present-day, bottomhole, temperature-based geothermal gradient map (Kalani et al., in press), Fig. 1B shows trends and contrasts which are likely linked with the major, normal, boundary fault systems controlling the present-day configuration of the Egersund basin area. Highest thermal gradients were observed on the Stavanger Platform where thin sedimentary successions were deposited on the crystalline basement. Within the main Egersund Basin trough (wells of exploration block 9/2), relatively high thermal gradients could be linked to the thick overburden layers. To the west, a meaningful contrast of thermal gradients of wells in exploration block 9/4 compared to those in block 9/2 is likely linked with the different thermal regimes which are partly explained by relatively thinner depositional sequences and thicker salt layers. The thermal gradients are in general agreement with the productivity of the wells. With similar depositional settings, wells within the main Egersund Basin trough (wells of block 9/2) were oil producing (e.g., well 9/2-1) whereas wells of block $9 / 4$ were reportedly dry. Furthermore, within block $9 / 2$ wells of relatively lower thermal gradients (e.g., well 9/2-2) showed only minor oil and gas.

Fig. 2 shows a seismic profile and lithostratigraphic units across the Egersund Basin. The coarse-grained units of the Vestland Group are overlain by the Upper JurassicLower Cretaceous fine-grained succession of the Boknfjord Group which, in turn, is overlain by the Lower Cretaceous shale-dominated Cromer Knoll Group. The Cenozoic succession comprises the Rogaland, Hordaland and Nordland groups. Particularly, the Hordaland and Nordland groups are shale dominated. The Rogaland Group contains a more hetrolithic succession compared to the Hordaland and Nordland groups. In addition to the rift phases, the Egersund Basin has also experienced phases of tectonic inversion during the Late Cretaceous as well as Cenozoic uplift and erosion linked to the opening of the North Atlantic Ocean and the Alpine Orogeny (Fjeldskaar et al., 1993; Jensen \& Schmidt, 1993; Mogensen \& Jensen, 1994; Jackson et al., 2013).

\section{Material and methods}

Log data of three exploration wells from two adjacent hydrocarbon exploration blocks (two wells 9/2-1, 9/2-2 from block 9/2 and one well 9/4-4 from block 9/4) were analysed. Volume of shale $\left(\mathrm{V}_{\text {sh }}\right)$ was estimated using the gamma ray index $\left(\mathrm{I}_{\mathrm{GR}}\right)$ corrected after Larionov (1969) for the Cenozoic and sub-Cenozoic stratigraphic intervals. A shale fraction cut-off of $0.5\left(\mathrm{~V}_{\text {sh }}>50 \%\right)$ was considered sufficient to discriminate shale-dominated units from other lithologies (Fig. 3). The compaction trends for finegrained sediments derived from experimental compaction of synthetic mudstones composed of $100 \%$ smectite (Mondol et al., 2007) and 50-50\% kaolinite-silt mixtures (Mondol, 2009) were used for comparison. Smectite is the most fine-grained clay and has a high cation exchange capacity and a very large surface area, and was used as an analog for the least permeable and compactable clay composition encountered in the studied successions reflecting the highest potential for overpressured zones. Mineralogical analyses of the studied sections show around $70-75 \%$ of clay minerals in the bulk samples. There is no single, ideal, representative, laboratory-tested synthetic clay mixture with respect to the studied sections. The 25:75\% silt-clay ratio can be the most relevant, representative, mechanically compacted synthetic mixture available. Mondol (2009) showed that the petrophysical properties (e.g., porosity) of a 50:50\% silt-kaolinite laboratory tested mixture falls within the range of a natural $25: 75 \%$ silt-clay mixture similar to the material studied in this work. Using a cut-off value of $50 \%$ shale volume $\left(\mathrm{V}_{\text {sh }}\right)$ would also ensure that the log-derived physical properties correspond to those which were experimentally measured. In practice, there is a good correlation between the physical properties of experimental synthetic mudstones and log-derived petrophysical properties in only marginally uplifted locations (e.g., block 9/4). The chosen experimental compaction trends were compared with the observed compaction trends in the study area shown by the well log data (depth-velocity and depth-resistivity). To perform this comparison, a constant conversion factor of $10 \mathrm{MPa}$ (100 bar) vertical effective stress per kilometre of burial depth was used.

As is common for mudrocks, unavailability of pressure data may be compensated for by using mud weights (Barriol et al., 2005). The reported mud weight data were adopted from the Norwegian Petroleum Directorate Fact Pages (NPD, 2014). Estimated pore pressure based on the sonic data calculated from Eaton's equation (Equation 2) was compared with the reported mud weight data in the area. Formation Multi-Tester (FMT) shut-in pressure measurements derived after well testing analyses from deeply-buried sand-dominated reservoir rocks were used in pressure depth plots to compare between the mud weight gradients and Eaton's calculated pore pressure. The NCT was established graphically, for each individual well, after fitting the best trend line to the logarithm of sonic transit time values corresponding to fine-grained mudstones plotted vs. burial depth, and the overburden gradient was calculated based on the trend of mudstone bulk densities with depth (Hottmann \& Johnson, 1965).

X-ray diffraction (XRD) patterns of 100 cutting samples from three of the studied wells $(9 / 2-1,9 / 2-2$ and 9/4-5) were acquired for both bulk (whole sample) and clay fractions $(<2 \mathrm{~mm}$ grain size oriented samples). Since the cutting samples of well $9 / 4-4$ were not available for this study, the available mineralogical data of well $9 / 4-5$, located less than $4 \mathrm{~km}$ from well $9 / 4-4$, were used. The XRD patterns of the samples were acquired using a D8 Advance Bruker diffractometer with $\mathrm{Cu} \mathrm{K} \alpha$ radiation, and a LynxEye detector enabled for tight energy discrimination limits to reduce iron fluorescence effects. The data 


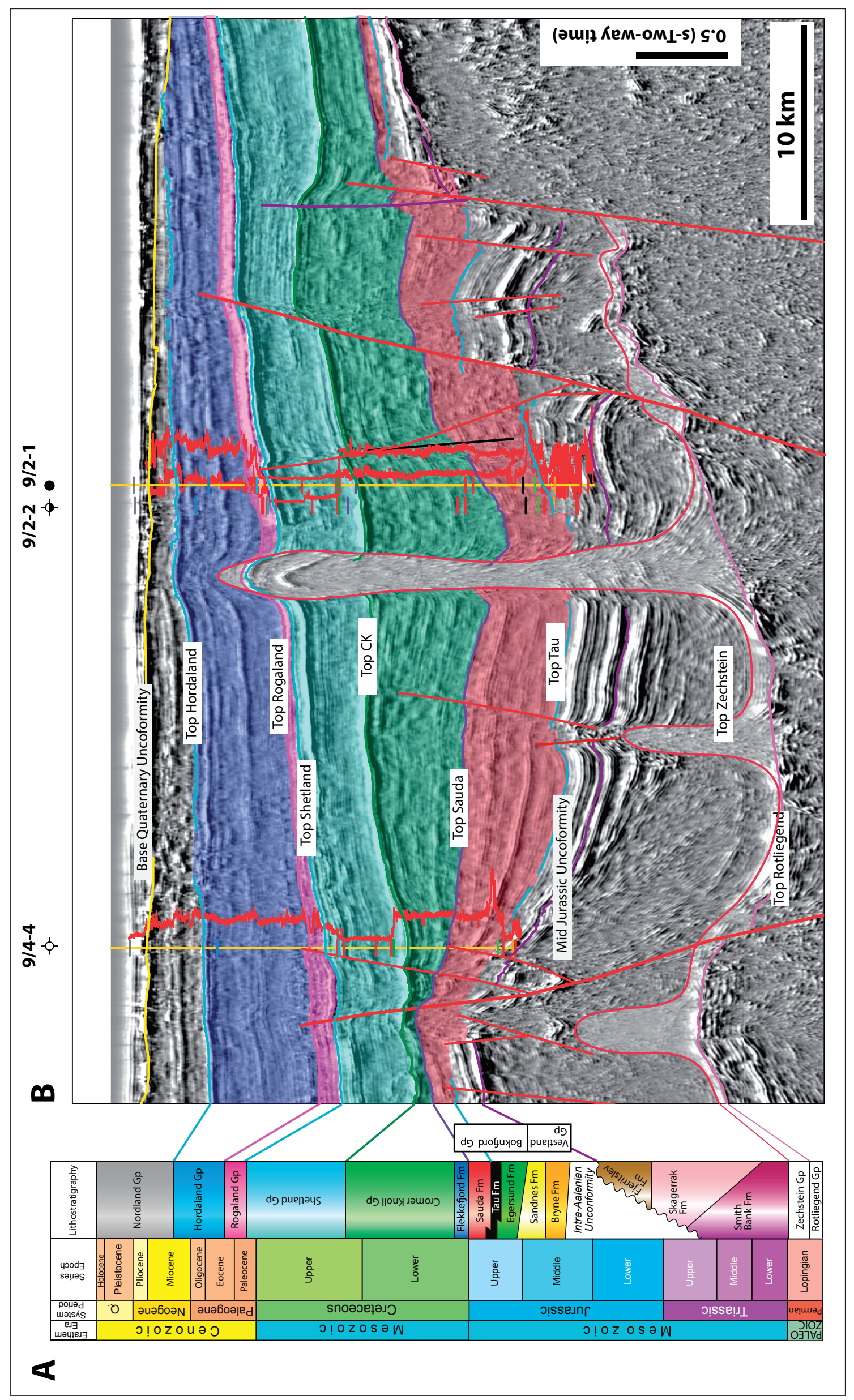

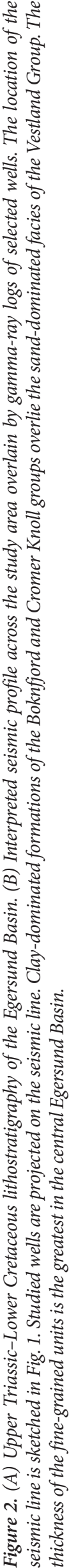



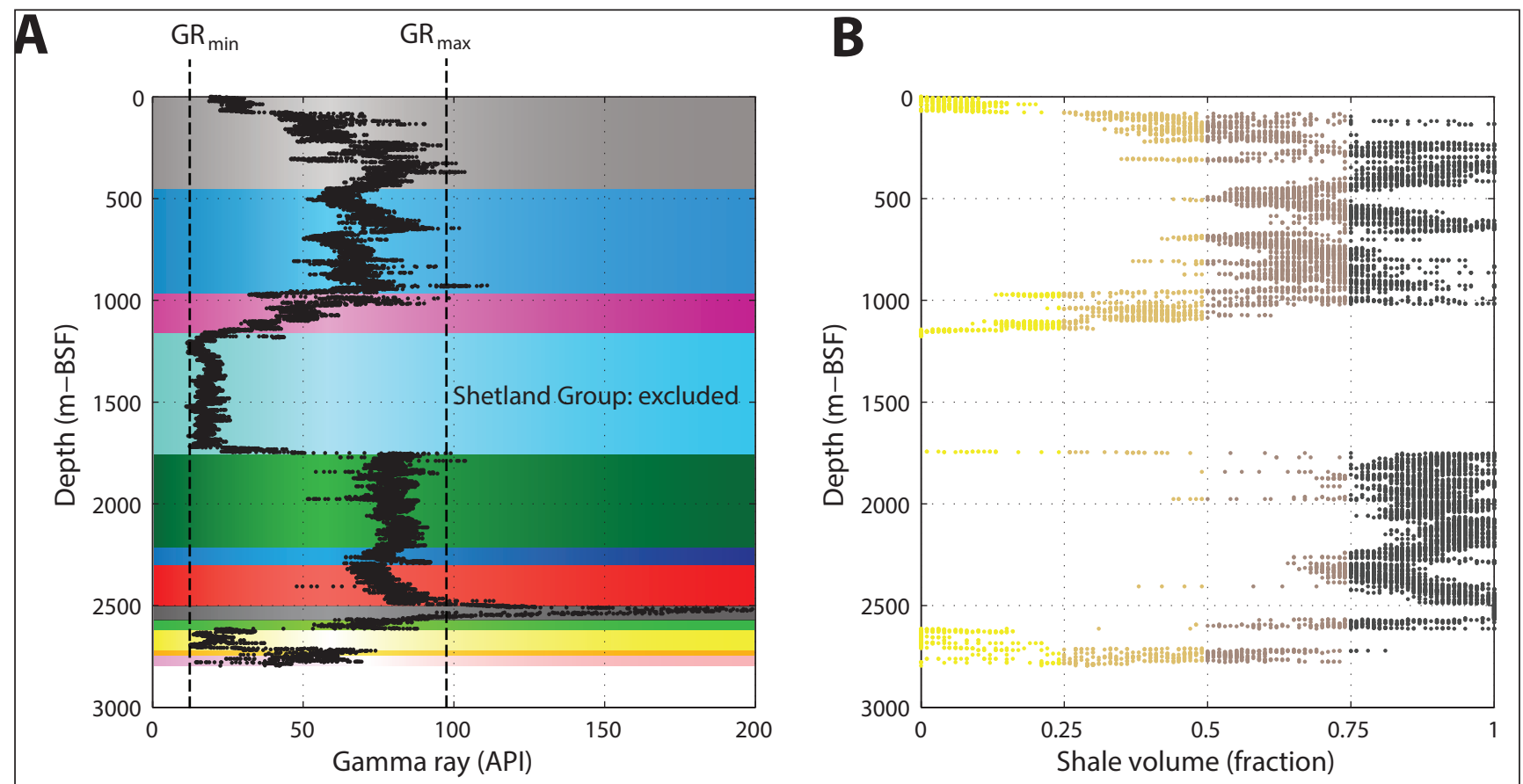

Figure 3. (A) A typical example of the gamma ray plotted vs. depth from well 9/4-4. For the lithostratigraphic legend, see Fig. $2 A$. (B) Calculated shale volume. The shale volume fraction $>0.5$ has been considered as shales and mudstones. The Shetland group (chalk) has been excluded in this study.

were collected from 2 to $65^{\circ} 2 \theta$ for non-treated bulk and clay samples, and $2-35^{\circ} 2 \theta$ for clay samples treated with ethylene glycol and heating. The BGMN software (Bergmann et al., 1998) was utilised to quantify the mineralogical phases in the bulk samples.

Scanning electron microscopy (SEM) analyses were carried out using a JEOL JSM-6460 LV SEM system with an embedded Oxford Instruments INCA-X-sight energy dispersive spectroscopy system (EDS). Total organic carbon content (TOC wt.\%), $\mathrm{T}_{\max }$ and bottom-hole temperature measurements were adopted from the Norwegian Petroleum Directorate Fact Pages (NPD, 2014).

\section{Results}

Rock property evolution and pore-pressure distributions

Pore-pressure and gamma-ray variations with depth compared to $\mathrm{P}$-wave velocity $(\mathrm{Vp})$ and formation resistivity changes in wells $9 / 2-1,9 / 2-2$ and 9/4-4 are shown in Fig. 4. Vp calculated from sonic transit time and deep resistivity is plotted as a function of depth below sea floor (BSF). Vp shows a general increasing trend with depth as a response to compaction processes reflecting both physical and chemical diagenesis.

The measured Vp of two wells (9/2-1 and 9/2-2) deviates substantially from the experimental mechanical compaction curve even at shallow depths corresponding to low temperatures where siliciclastic chemical compaction is not expected (Fig. 4A, B). However, the Vp measured in well 9/4-4 approximately follows the mechanical experimental compaction curve down to around 2 $\mathrm{km}$ depth, showing rather normal burial and compaction of sediments at this well location (Fig. 4C). This indicates that more exhumation has taken place in the area where the wells $9 / 2-1$ and 9/2-2 are located (around $700 \mathrm{~m}$; Kalani et al., in press) compared to the area where well 9/4-4 is situated (around $200 \mathrm{~m}$ ). Estimated exhumation based on experimental mechanical compaction curves is in general agreement with earlier estimates based on vitrinite reflectance and seismic reflection profiles (Irwin et al., 1993; Jensen \& Schmidt, 1993). The estimated exhumations, however, are larger particularly in block $9 / 2$. Such a difference between exhumation estimated from vitrinite reflectance compared to shale compaction curves has previously been mentioned by Fjeldskaar et al. (1993) for well 9/2-1; i.e. 400 vs. 600 m. Conventional exhumation estimation using shale compaction curves includes the fitting of log-derived data with the theoretically calculated trends (e.g., Heasler \& Kharitonova, 1996). In our approach, the Vp vs. depth curve of a representative synthetic mud mixture (i.e. $50-50 \%$ kaolinite-silt mixtures; Mondol, 2009) was used as a guideline to detect the transition from mechanical to chemical compaction in the studied mudrocks. This has the advantage of being based on experimental data rather than theoretical data. However, one should consider the disadvantage of synthetic mixtures as ideal representative equivalents for natural mudstones and/or shales. Different basin histories in different wells of the study area may also introduce different pore-pressure profiles. 

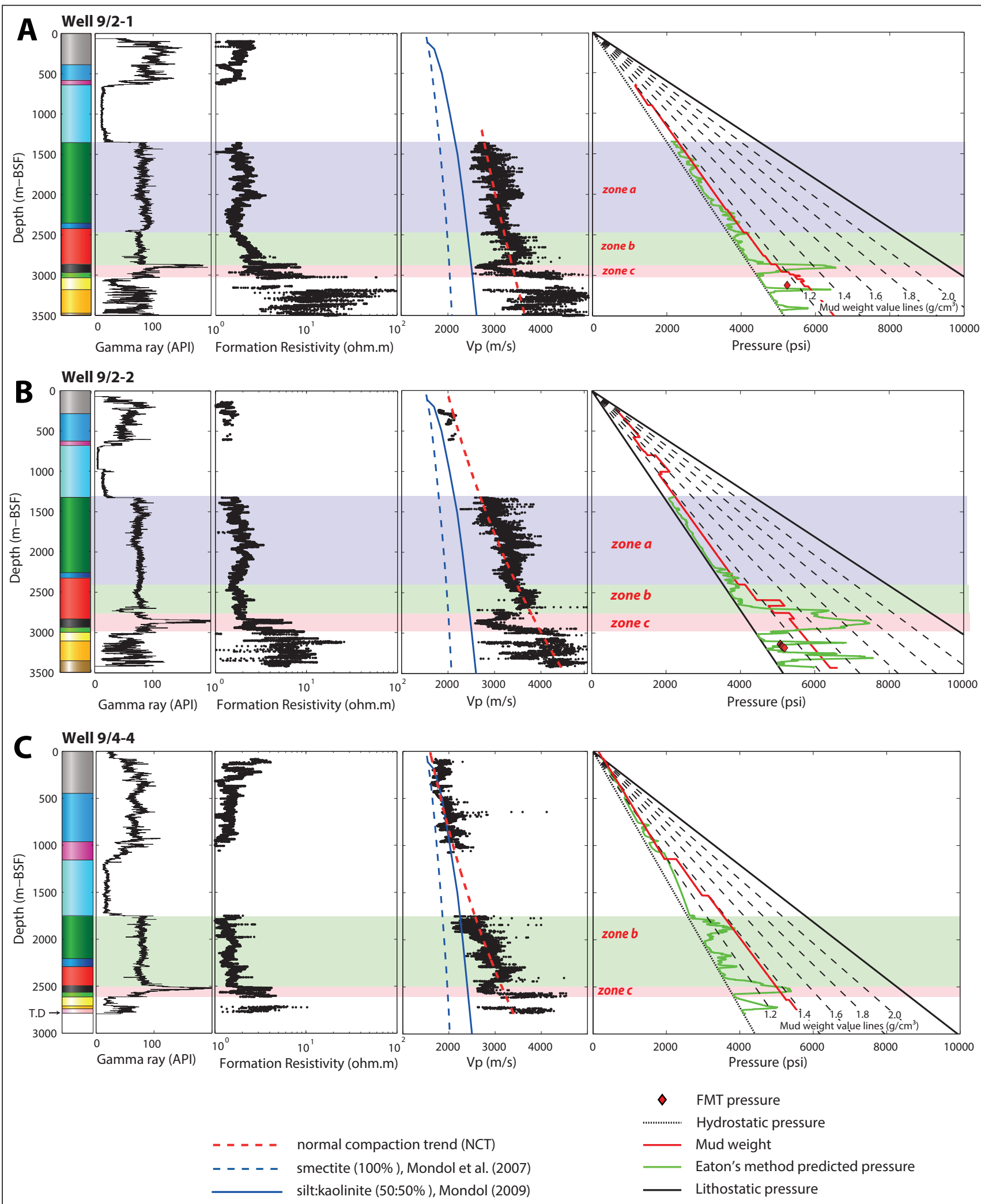

Figure 4. Reported and predicted pore-pressure variation, gamma ray, Vp and formation resistivity changes of (A) well 9/2-1, (B) well 9/2-2 and (C) well 9/4-4 as a function of burial depth. Three zones of pore-pressure variations are highlighted and labelled as zones $a, b$ and $c$. The Vp-depth plot is superimposed by NCT curves and trends of mechanically-compacted synthetic samples of smectite aggregate and 50:50 sand-kaolinite mixture. For the lithostratigraphic legend, see Fig. 2 A. 
In each studied well, three different zones of pressure regimes with different rock property behaviour can be detected within the Lower Cretaceous and Upper Jurassic fine-grained sediments (Fig. 4):

- Zone $\boldsymbol{a}$ where the pore pressure is hydrostatic. This zone is identified in wells $9 / 2-1$ and 9/2-2 within the Lower Cretaceous Cromer Knoll Group and Flekkefjord Formation. It also occurs at a shallower depth in well $9 / 4-4$ which is not an interval of interest in this work. In wells 9/2-1 and 9/2-2, both $\mathrm{Vp}$ and resistivity show a linear increasing trend for the upper part of zone $\boldsymbol{a}$ as a function of depth, while no significant change in gamma ray response is visible (Fig. 4A, B). Below this zone, the physical properties begin to show variation mainly in response to the lithological variations indicated by the gamma-ray readings (Fig. 4).

- Zone $\boldsymbol{b}$ where the pressure is elevated compared to hydrostatic pressure. Zone $\boldsymbol{b}$ includes almost the whole of the Sauda Formation in block 9/2. Moreover, this zone includes the Cromer Knoll Group and continues down to the upper Sauda Formation in block 9/4. In well $9 / 2-1$, the gamma-ray response does not show any significant variation throughout zone $\boldsymbol{b}$. A minor increase in the reported mud weight data occurs close to the top of the Sauda Formation that slightly exceeds hydrostatic conditions, while Eaton's predicted pore pressure formula estimates a much higher overpressure. Both Vp and resistivity show rapidly increasing trends with depth in this well (Fig. 4A). However, this trend changes within the deeper parts of the Sauda Formation resulting in a decreasing trend with burial depth (Fig. 4A). In well 9/2-2, a similar change in the rock properties can be distinguished within zone $\boldsymbol{b}$. An overpressure regime can be assumed in the upper part of the Sauda Formation based on an abrupt shift in mud weight data ( 2500 m-BSF, Fig. 4B). In well 9/4-4, the zone $\boldsymbol{b}$ is better developed where a relatively high overpressure ( $700 \mathrm{psi}$ ) can be detected (Fig. 4C). This forms a pressure ramp at $\sim 1400 \mathrm{~m}$-BSF down to the base of the Sauda Formation.

- Zone $c$ is a zone with excess overpressure compared to the overlying zone $\boldsymbol{b}$. It includes the lower part of the Sauda Formation and the whole of the Tau and Egersund formations. This zone consists mainly of organicrich shales based on high to very high gamma-ray values of the included layers (Fig. 4). In all the wells, a reverse trend of log-derived $\mathrm{Vp}$ with increasing depth is observed in the upper part of zone $c$ comprising the Sauda and Tau formations, while the resistivity shows a relatively rapidly increasing trend (Fig. 4). The Vp and resistivity reach their minimum and maximum values, respectively, within the Tau Formation which is the most organic-rich layer in the study area. Above the Tau Formation, Vp shows an increasing trend and resistivity a decreasing trend in the Egersund Formation (Fig. 4). A large deviation of reported mud weights relative to the hydrostatic pressure trend is obvious in this zone, indicating the occurrence of high overpressure within the organic-rich shale and mudstone sections (Fig. 4).

\section{Mineralogical composition and burial diagenesis}

Mineralogical compositions of the Cenozoic Lower Cretaceous and Upper Jurassic intervals predominantly comprise three main categories: clay minerals + mica, quartz + feldspars and carbonates (Fig. 5). Pyrite (less than $2 \%$ of the bulk mineralogy) is not included in any of these subdivisions. The amount of carbonate minerals is generally less than $10 \%$. However, minor increases of carbonates can change the rock properties quite noticeably (e.g., Vp and resistivity). Quartz and feldspars do not change significantly with depth. Similarly, the mica content is fairly stable as a function of depth. Overall, the clay minerals are the most variable mineral category (Figs. 6 \& 7). The variation in clay composition is related to provenance, depositional environment and diagenetic processes. The Cenozoic sediments, particularly the fine-grained sections, are generally low in smectite (Fig. 5). Lack of smectite increases permeability and results generally in hydrostatic pressures. On the other hand, the mineralogical variations seen in the Cromer Knoll and Boknfjord groups control the formation of overpressure more significantly (Figs. $6 \& 7$ ).

Kaolinite is generally high in the Cromer Knoll Group (Figs. 6 \& 7A, B), whereas in the Boknfjord Group the kaolinite content is lower and other clay minerals, particularly smectite, show a notable increase (Fig. 7C). The onset of chemical compaction processes are inferred from well log data and confirmed by XRD (Fig. 7A, B) and SEM analyses (Fig. 8A). An increase in Vp in the Cromer Knoll Group is coincident with the occurrence of micron-size quartz crystals (Figs. 4, 6 \& 8). The criteria used to differentiate micron-size diagenetic quartz grains from the detrital ones have been outlined elsewhere (Kalani et al., in press). The most important criteria are: textural parameters including the micrometre size, high roundness and sphericity, relation to illite formation evident from EDS response and characteristic CL spectra. The onset of chemical compaction occurs in pore pressure zone $\boldsymbol{a}$ and does not impose a significant pressure build-up. Although chemical compaction is more intense close to the top of the Sauda Formation causing a notable Vp deviation (Fig. 4), the amount of chemical compaction can be determined from mineralogical and petrographic observations (Figs. 6, 7 \& 8). Many factors may contribute to illitisation, the most important factor being the availability of a reactive clay mineral (smectite) within the sedimentary section. The smectite content is variable due to continuous changes within the depositional system. The observations in this study are in agreement with earlier key works in the field of illitisation of smectite (Perry \& Hower, 1972 and references therein). 


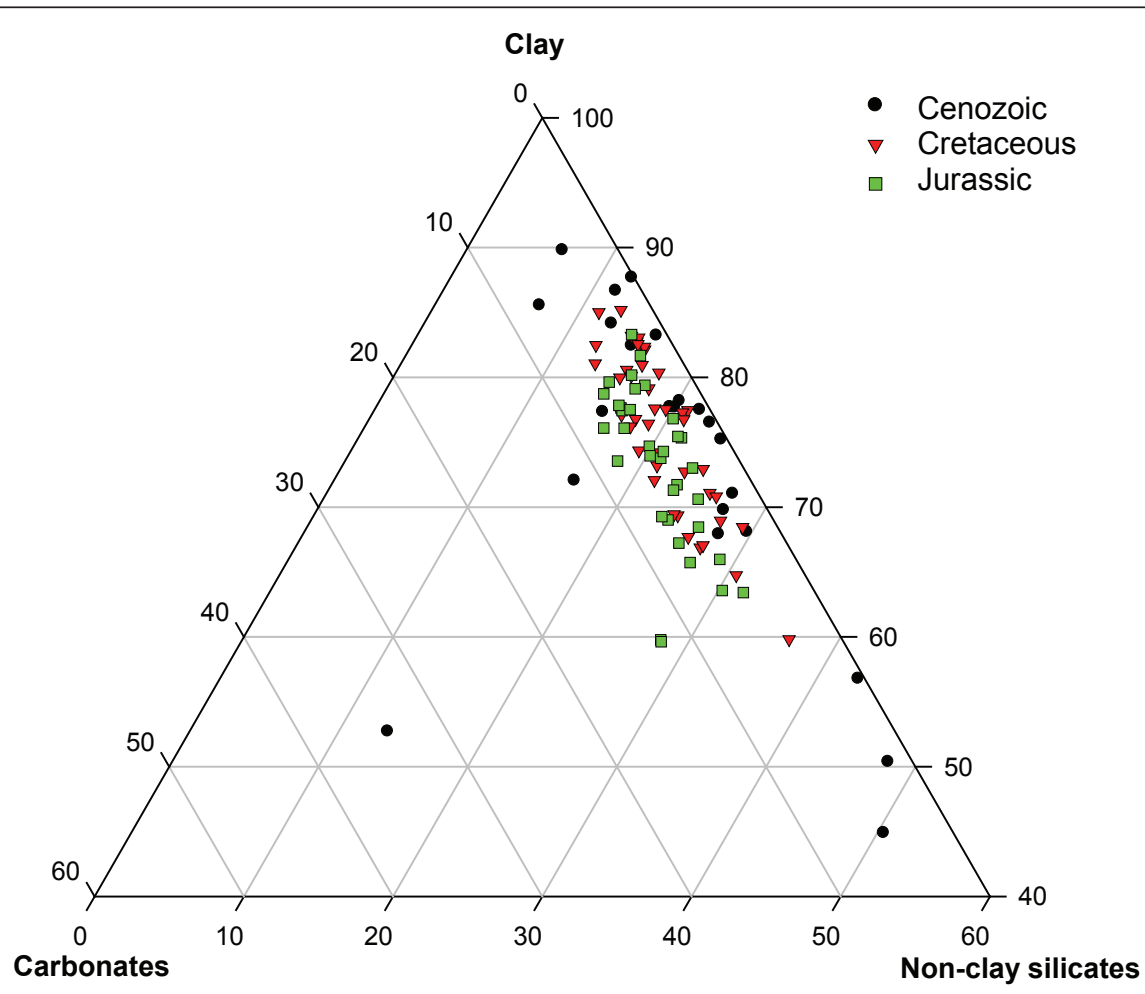

Figure 5. Ternary diagram showing the main mineral phase categories in the selected wells of the Egersund Basin: clay minerals, quartz + feldspars and carbonates. Data points plot mainlyin a narrow zone with less than $10 \%$ carbonate minerals.

The overpressure zone resulting from chemical compaction processes is labelled as zone $\boldsymbol{b}$ in Figs. 4 \& 6. The higher overpressure found in the Cromer Knoll Group in well 9/4-4 is likely linked to higher carbonate cementations in this interval, as implied by mineralogy and SEM petrography of the adjacent well 9/4-5 (Fig. 6; Kalani et al., in press).

\section{Organic carbon content and maturation}

The Lower Cretaceous Flekkefjord Formation and Cromer Knoll Group as well as the Upper Jurassic Egersund and Sauda formations are less organic-rich $(0.5<$ TOC < 1, Fig. 9) compared to the Tau Formation (Fig. 9). The lower part of the fine-grained Sauda Formation shows a gradual upward increase in TOC values (Fig. 9).The high organic carbon content found particularly in the Tau Formation (confirmed petrographically in Fig. 10) make this formation the most important potential source rock since the Mid Jurassic in the study area.

Fig. 11 shows $\mathrm{T}_{\max }$ as a function of increasing depth. A notable increase of $\mathrm{T}_{\max }$ occurs close to the top of the Tau Formation. Overall, wells $9 / 2-1$ and 9/2-2 show notably higher thermal maturities compared to $\mathrm{T}_{\max }$ data from well 9/4-5. The higher thermal maturity of organic matter in wells $9 / 2-1$ and $9 / 2-2$ than in wells 9/4-4 and 9/4-5 is in agreement with the deeper burial and corresponding temperature increase. Such contrasts in thermal maturities of the organic carbon content through the Egersund Basin area were also mentioned in earlier, more detailed, organic geochemical studies (Ritter et al., 1987; Ritter, 1988).

Source-rock maturation involves transformation of solid organic matter into fluid hydrocarbons. The decrease of load bearing solid material and volume increase involved in this process may result in a local build-up of pore pressure. The Egersund and Sauda formations are low in organic content. Hence, overpressure as a result of hydrocarbon generation in these formations is less probable than in the organic-rich intervals. Hydrocarbongenerated overpressure may, however, be significant in the finer-grained lower part of the Sauda Formation which shows relatively high TOC values.

The higher maturity of Tau Formation in wells 9/2-1 and 9/2-2 compared to well $9 / 4-4$ has a direct effect on the recorded log responses. As $\mathrm{Vp}$ and resistivity are governed by TOC and the amount of fluid hydrocarbons, the relatively higher resistivity in parallel with the relatively lower $\mathrm{Vp}$ in wells $9 / 2-1$ and $9 / 2-2$ may result from higher thermal maturities and consequently have a higher potential for overpressure build-up (Fig. 4). 


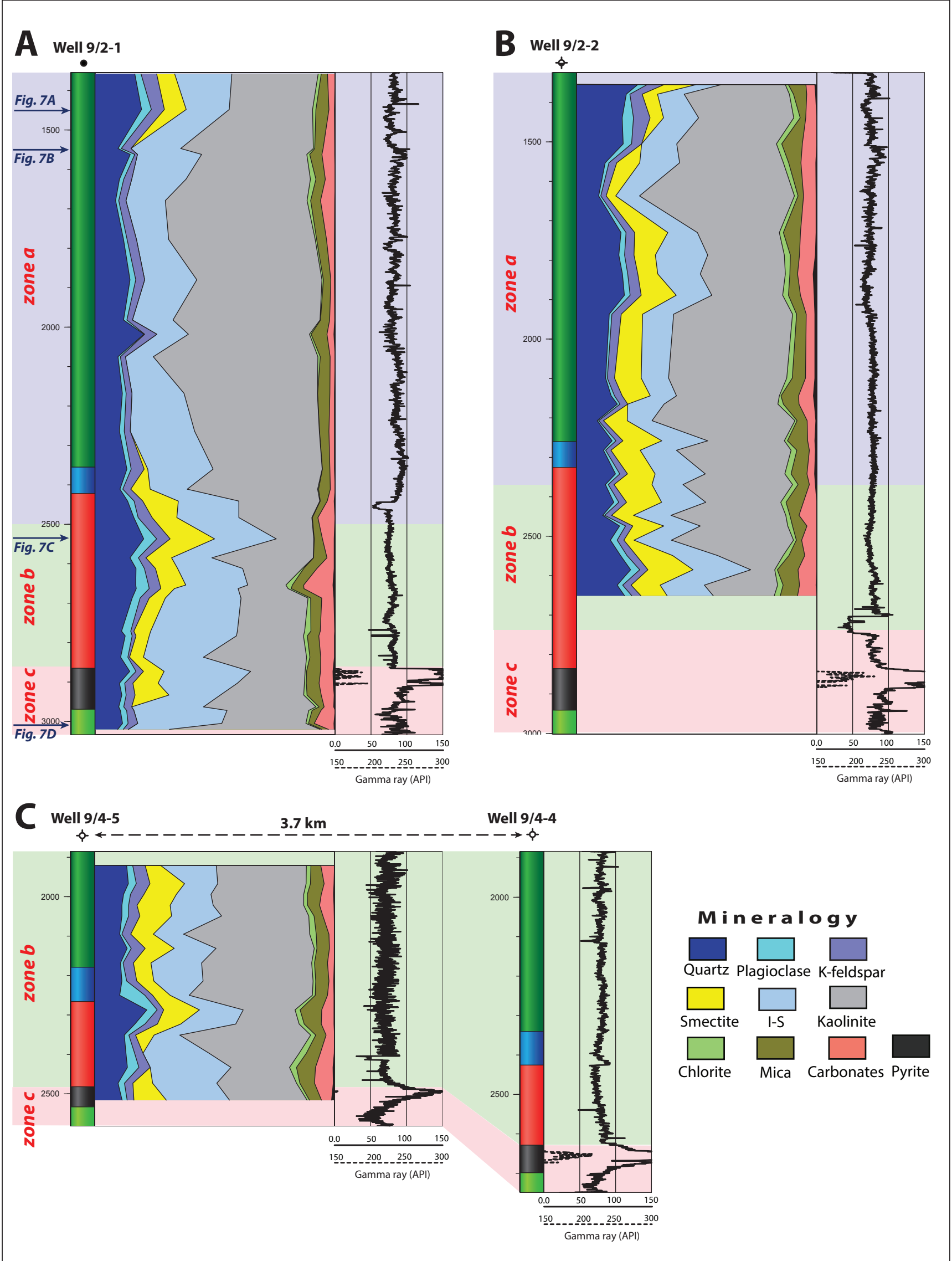

Figure 6. Mineralogical composition, lithostratigraphy and gamma-ray response in the selected wells of the Egersund Basin. Mineralogical and lithological data are in agreement with the pressure build-up zones defined as zones $a, b$ and $c$. (A) well 9/2-1, (B) well 9/2-2, (C) well 9/4-5. Due to the relatively short distance between well 9/4-5 and well 9/4-4 and similar lithological and physical properties, mineralogical data available in well 9/4-5 are representative of those in well 9/4-4. For the lithostratigraphic legend, see Fig. $2 \mathrm{~A}$ 

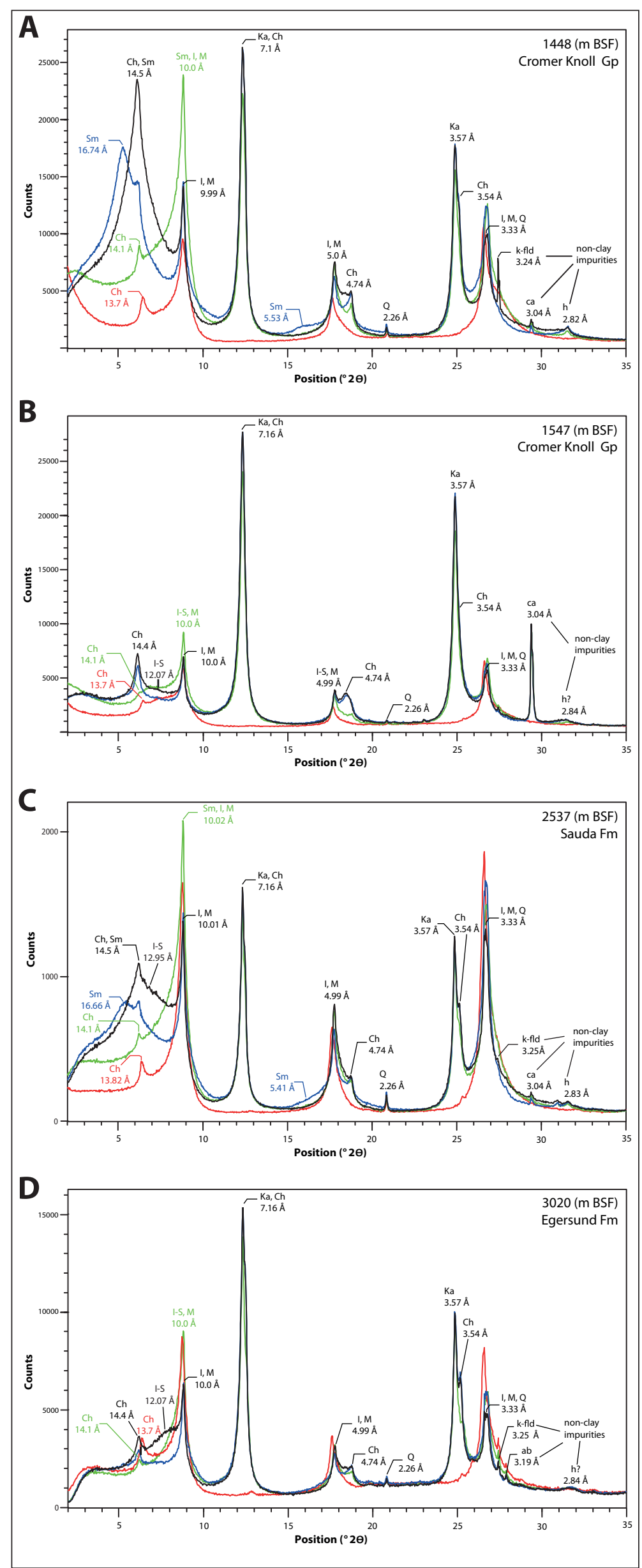

Figure 7. Representative examples of XRD patterns of the oriented clay fractions of samples from well 9/2-1. XRD patterns in black - Mg-saturated air-dried, blue glycolated, green - heated at $400^{\circ} \mathrm{C}$, red - heated at $550^{\circ} \mathrm{C}$. Abbreviations: I - illite, I-S - illite-smectite, Sm - Smectite, $M$ - mica, Ka - kaolinite, $k$-fld - K-feldspar, Ch - chlorite, $Q$ - quartz, ca - calcite, $h$ - halite, ab-albite. 

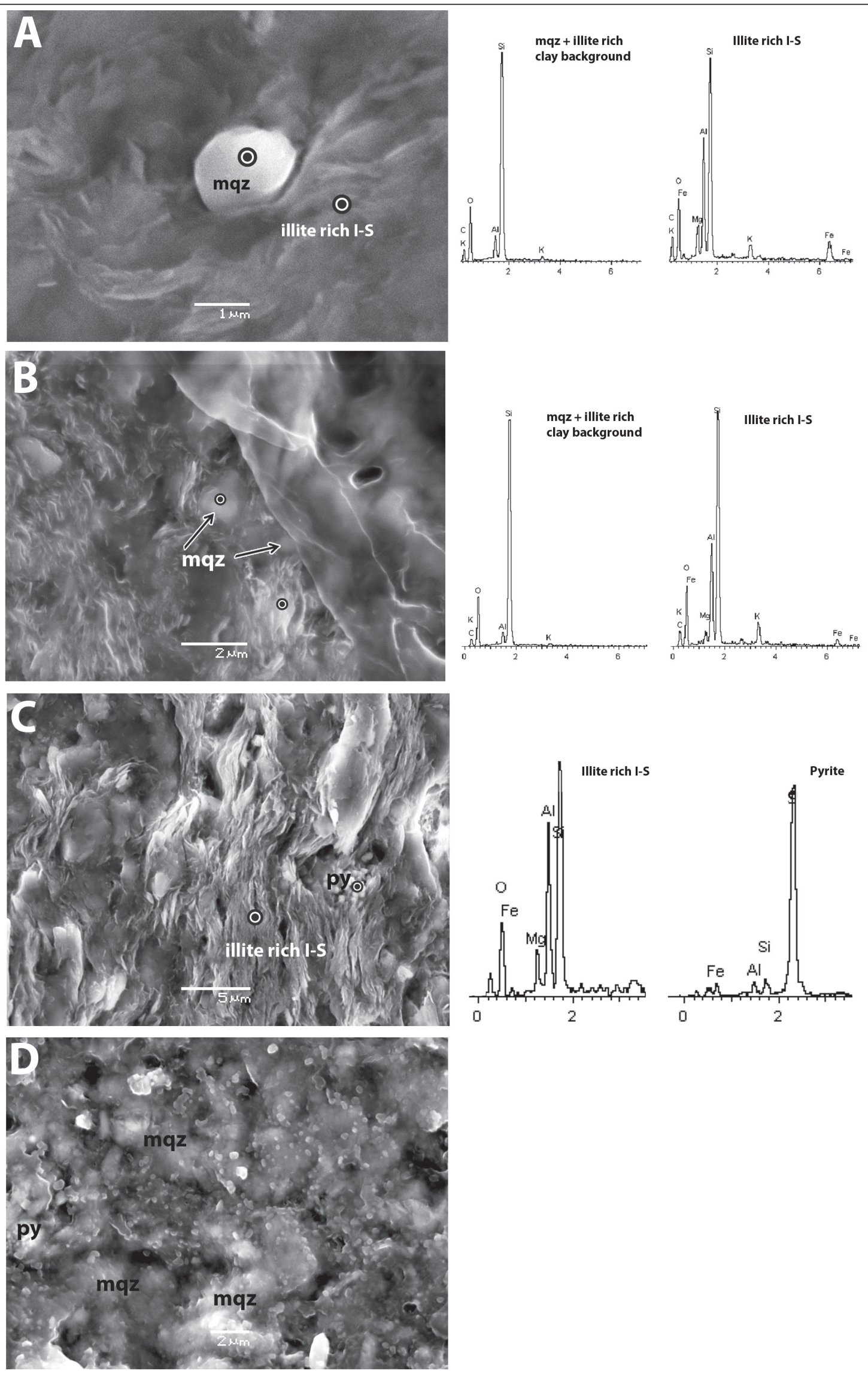

Figure 8. SEM back-scattered images as petrographic evidence of chemical compaction processes (i.e., illitisation). With increasing depth chemical compaction is increased which is partly implied by more micron-sized quartz crystals and/or condensed illite-rich l/S fabrics. (A) Single microquartz crystal (mqz) associated with illite-rich I-S observed in the upper part of the Cromer Knoll Group (2022 m-BSF). (B) Flekkefjord Formation (2250 m-BSF). (C) Well oriented, chemically compacted, illite-rich clays in the Sauda Formation (2433 m-BSF). (D) Intensive microquartz cementation in the Tau Formation (2529 m-BSF). Abbreviation: Py - pyrite. 


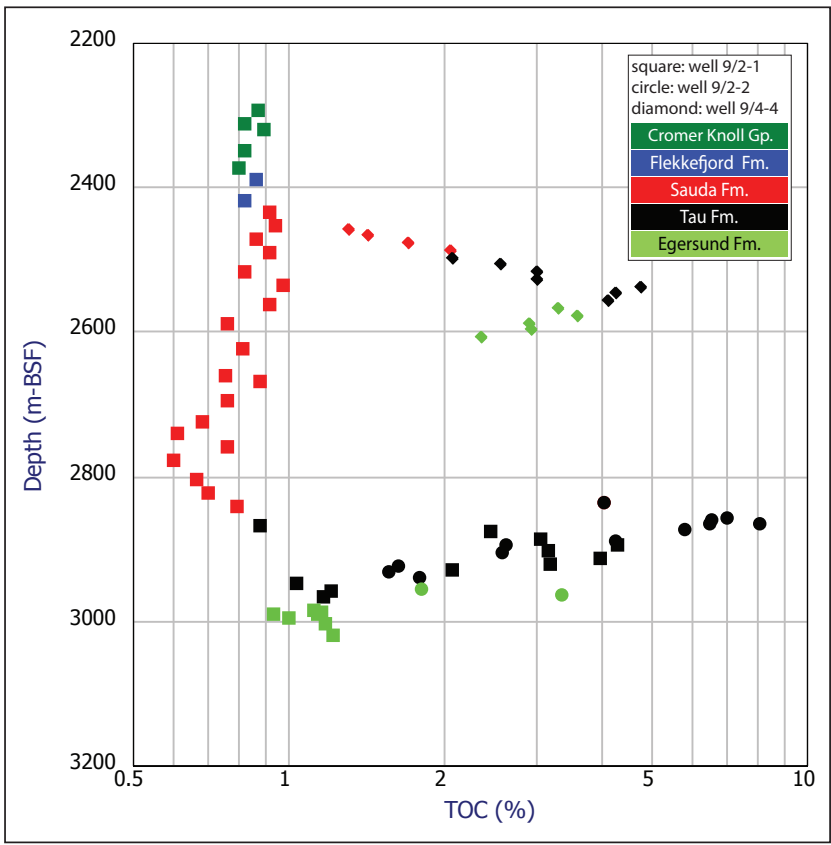

Figure 9. TOC variations with increasing depth. The Tau Formation (Kimmeridgian to Early Volgian) shows the highest TOC content and is generally regarded as the most important post-Mid Jurassic source rock in the Egersund Basin.

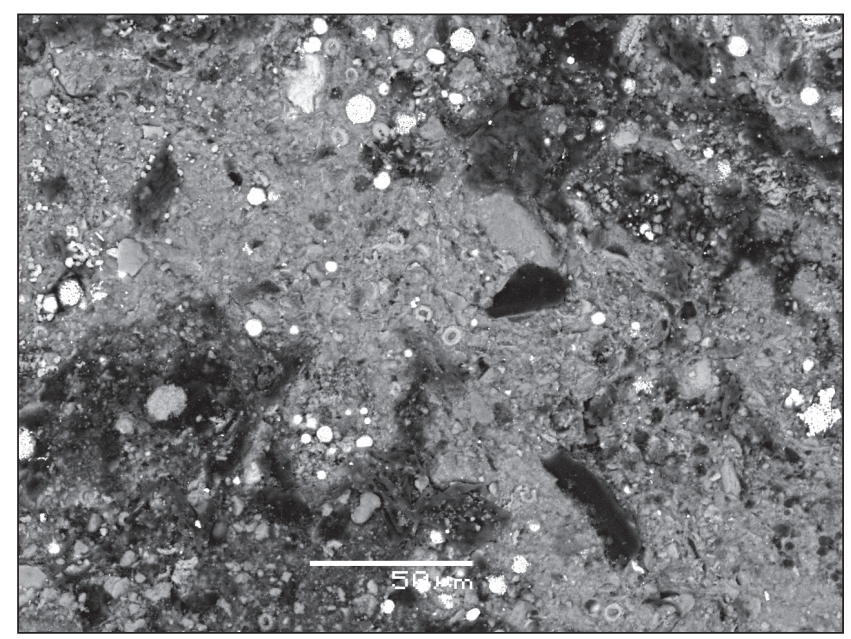

Figure 10. SEM back-scattered image showing organic matter distribution, identified as dark tone areas, in a sample of the Tau Formation in well 9/4-5 (2516 m-BSF). More examples of organic matter fabrics in the study area, including block 9/2 (i.e., well 9/2-A-5 which was not mentioned in this paper), can be found in Kalani et al. (2015).

\section{Discussion}

\section{Factors affecting overpressure distribution}

The pore pressures adapted from the NPD Fact Pages (NPD, 2014) for the three studied wells show overpressures in the fine-grained successions. Several factors may play a role in overpressure generation. In this work, the available data do not allow quantification of all factors affecting overpressure generation. However, the importance of the interplay between diagenetic processes and sediment composition is highlighted. Notably, the permeability distribution controls the fluid transfer and consequently overpressure in the layers of interest. The occurrence of thick, Upper Jurassic-Lower Cretaceous, mainly fine-grained successions in the Egersund Basin effectively increases the overpressure generation potential of these sediments.

\section{Disequilibrium compaction}

The burial depth of the pore pressure build-up and the log-derived compaction trends compared to the experimental mechanical compaction trends (Mondol et al., 2007; Mondol, 2009) show the link between overpressure development and diagenetic processes. The undercompaction observed is typical of low-permeability Cenozoic sedimentary units (e.g., Mondol et al., 2008b; Goulty \& Ramdhan, 2011, 2012). The Cenozoic successions are mostly mechanically compacted. Due to the relatively low temperatures and shallow burial depths, the chemical diagenetic processes are not important. In such an interval, the high bulk smectite content may result in overpressure (Swarbrick \& Osborne, 1998; Swarbrick et al., 2002). However, the sections studied herein contain less smectite in the fine-grained successions ( 20\%) compared to bulk smectite contents documented to be threshold values for mechanical compaction retardation in the sedimentary basins (Marcussen et al., 2009). The higher smectite percentages found in the relatively coarse-grained intervals of the Rogaland Group may not support the concept of overpressure generation due to the overall higher permeability of these sediments.

\section{Chemical compaction}

At deeper levels and higher temperatures (above about $70^{\circ} \mathrm{C}$ ), however, the primary smectite content in the presence of reactive $\mathrm{K}^{+}$may convert to illite-rich I-S mixed layer clays. The process was summarised by Boles \& Franks (1979) as:

Smectite $+\mathrm{K}^{+} \rightarrow$ Illite + Quartz $+\mathrm{H}_{2} \mathrm{O}+$ exchangeable cations

As indicated above, illitisation involves replacement of more porous smectite and I-S mixed layered clays with less porous illite. Furthermore, the newly formed microquartz crystals may decrease the size of the pore throats significantly and strongly influence the permeability (Nadeau et al., 2002; Thyberg et al., 2010). In addition, the neoformed illite will be oriented parallel to the bedding (normal to the principal stress axis), decreasing the vertical permeability. Smectite and I-S will also release bound water resulting in an increased sediment fluid content. The illitisation process therefore results in both lower permeability and more compaction-derived water. This requires higher fluid expulsion rates to maintain the pressure at hydrostatic. As mentioned above, the illitisation requires a potassium source and the mobilisation of potassium is the rate-limiting factor for illitisation. 


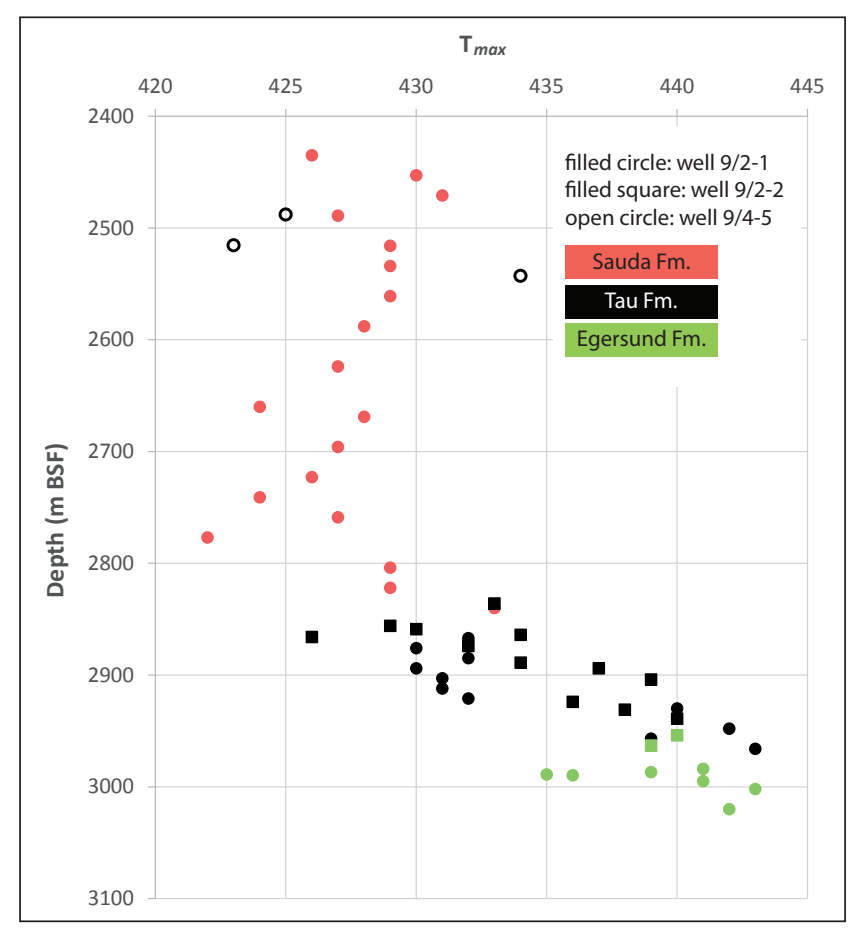

Figure 11. $T_{\text {max }}$ as a function of depth increase. A notable increase of thermal maturity is observed in the Tau Formation compared to the overlying Sauda Formation. Samples from the Tau Formation in wells 9/2-1 and 9/2-2 (filled symbols) show notably higher thermal maturities compared to those of well 9/4-5 (open circles).

In fine-grained sediments, illitisation is found to be a rather slow process with increasing depth/temperature. The nature of illitisation in clay-dominated sedimentary sections triggers a gentle pressure increase termed overpressure ramp by Nadeau (2011) and Nadeau et al. (2002). Progressive illitisation and quartz cementation is reflected by changes in petrophysical properties. $\mathrm{Vp}$ increases as a function of quartz cementation due to precipitation of stiffer crystals and increased cohesion across grain contacts. The formation resistivity increases as illitisation progresses since fresh crystal bound-water released from smectite reduces the pore water salinity (Marcussen et al., 2009). Such trends for Vp and formation resistivity are evident within zone $\boldsymbol{a}$ in Fig. 4.

Petrophysical and petrographic data suggest that chemical compaction processes are more intense within the deeper levels of the Upper Jurassic Sauda Formation compared to the overlying strata (Figs. 4 \& 8). The higher rates of illitisation within this zone may explain the pressure build-up observed in this study. In addition, petrographic evidence of carbonate reactions, e.g., calcite is replaced by ankerite (Kalani et al., in press), may also play a part in lowering permeability at this level. All the mentioned processes together may both decrease the pore space and decrease the size of the pore throats. Notably lower permeabilities coupled with released mineralbound water may therefore result in the build-up of high pore pressure. The availability of reactive clay and $\mathrm{K}^{+}$will profoundly affect the progress of pressure build-up in fine-grained sediments. Because the overall permeability of a sedimentary section is a function of the harmonic mean, the intervals with high contents of these reactive phases (smectite and K-feldspar) will dominate the pressure development. Where the overburden permeability is very low and diagenesis is very intensive (depth/ temperatures $>100^{\circ} \mathrm{C}$ ), the overpressure may even rise to fracture pressure level as a result of chemical compaction. However, as indicated by Kalani et al. (in press), compaction in fine-grained sediments is not purely chemical. It has also a mechanical compaction component because the rock frame is unable to retain all the porosity resulting from dissolution of reactive mineral grains (smectite and $\mathrm{K}$-feldspar).

\section{Maturation of organic matter}

In the organic-rich intervals, both chemical compaction and organic matter maturation may increase the fluid volume in the rock. Organic carbon richness is reflected by the gamma-ray response due to the elevated uranium content related to the anoxic conditions that existed during source-rock deposition. The reducing depositional conditions favouring organic matter accumulation also result in precipitation of uranium minerals in the sediments resulting in a high gamma-ray signature (e.g., Fig. 4). Due to the anisotropy related to the kerogen orientation in shales and mudstones, notably lower $\mathrm{Vp}$ values suggest higher TOC (Vernik \& Nur, 1992; Vernik \& Landis, 1996; Vernik \& Milovac, 2011). Based on this, the lower Vp values seen in well 9/4-4 imply on a higher TOC content in this well which is in agreement with the measured TOC (Fig. 9).

There is no direct link between illitisation and organic matter maturation forming hydrocarbons. According to Bruce (1984), the onset of peak oil generation may occur at depths above, within or below the zone of illite formation. In the Egersund Basin, the peak hydrocarbon generation (within the Tau Formation) is much deeper than for the onset of illitisation. In the Tau Formation, petrographic observations show a more pronounced illitisation compared to the overlying succession due to a higher temperature and availability of the reactive materials (Fig. 8D). Hydrocarbon generation has a pronounced impact on volume increase which may overprint the chemical compaction processes. Due to very low permeabilities, the pressure caused by hydrocarbon generation may not be dissipated through porefluid expulsion (Berg \& Gangi, 1999). The maturation of organic material is highly dependent on temperature and, hence, the maximum burial depth and the exhumation histories in the area could provide the kinetics for both reactions here.

In Fig. 12, Vp is plotted vs. formation resistivity for Tau and Egersund cutting samples for which TOC data were available. The Egersund data points show higher Vp compared to the Tau data points due to a lower TOC con- 


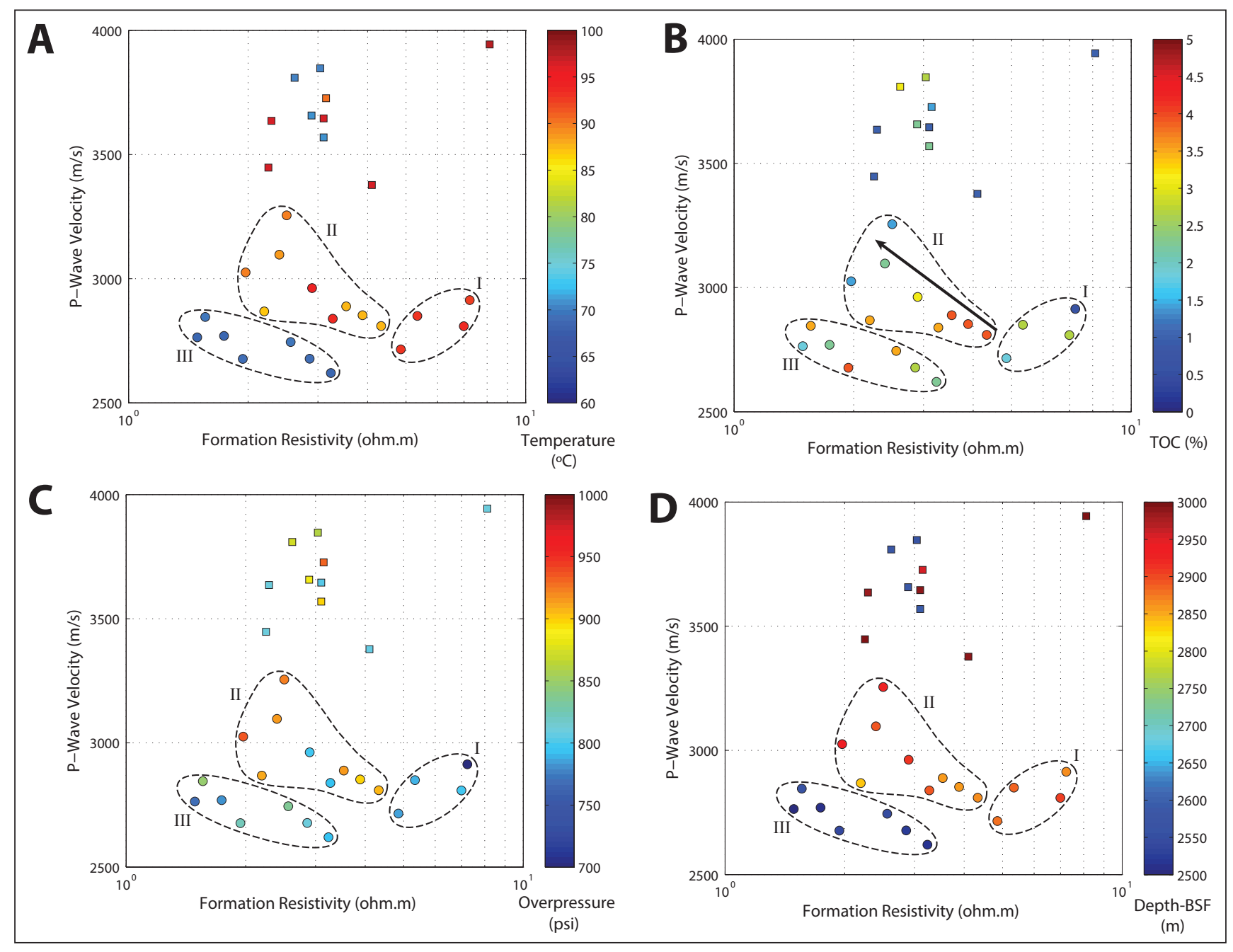

Figure 12. Vp as a function of formation resistivity for cutting samples of the Tau and Egersund formations, colour coded by (A) temperature, (B) measured TOC content, $(C)$ overpressure and $(D)$ burial depth. The squares represent the Egersund samples and circles represent the Tau samples.

tent in the Egersund Formation and also its greater burial depths (Fig. 12A). Unlike the Egersund Formation samples, the Tau Formation data points span a wide range of resistivity values. The resistivity is directly affected by the pore fluid saturating the porosity of the rock including the fracture porosity (Kalani et al., 2015). Therefore, resistivity has a direct link with the maturation of organic matter and hydrocarbon generation in organic-rich, finegrained sediments. Three different clusters with different characteristic Vp and formation resistivity can be discriminated within the Tau Formation sample data (Fig. 12). The samples within the cluster I represent the highest resistivity values among all the samples, which may indicate a higher maturity of the organic matter contained in these samples. The high present-day temperatures of the cluster I samples also indicate that they are more mature compared to the other samples (Fig. 12A). However, the organic content of the samples in this cluster is quite low compared to the rest of the samples (Fig. 12B). Thus, a relatively low pore pressure is indicated for the cluster I data points (Fig. 12C).
On the other hand, the cutting samples plotting within cluster II show higher TOC values (Fig. 12B), whereas they have been exposed to relatively lower temperatures compared to cluster I (Fig. 12A). The cutting samples of this cluster belong to the well 9/4-4 which penetrated the Tau Formation at a more shallow depth compared to the other two studied wells (Fig. 12D). Consequently, these data points show lower Vp values due to a high TOC content and lower resistivity values due to lower maturation and hydrocarbon generation. The cluster II data points depict a relatively moderate overpressure (Fig. 12C). The Vp values found for the cluster III samples reveal an increasing $\mathrm{Vp}$ trend with decreasing resistivity as outlined by the arrow in Fig. 12B. TOC decreases along the arrow (Fig. 12B). Furthermore, these data points do not indicate a significant temperature variation (Fig. $12 \mathrm{~A})$. When the sample temperature is similar, higher resistivity values can be expected for the samples with higher TOC due to a higher hydrocarbon generation potential (cluster III in Fig. 12B). Unlike TOC, the overpressure distribution does not show any definitive trend 


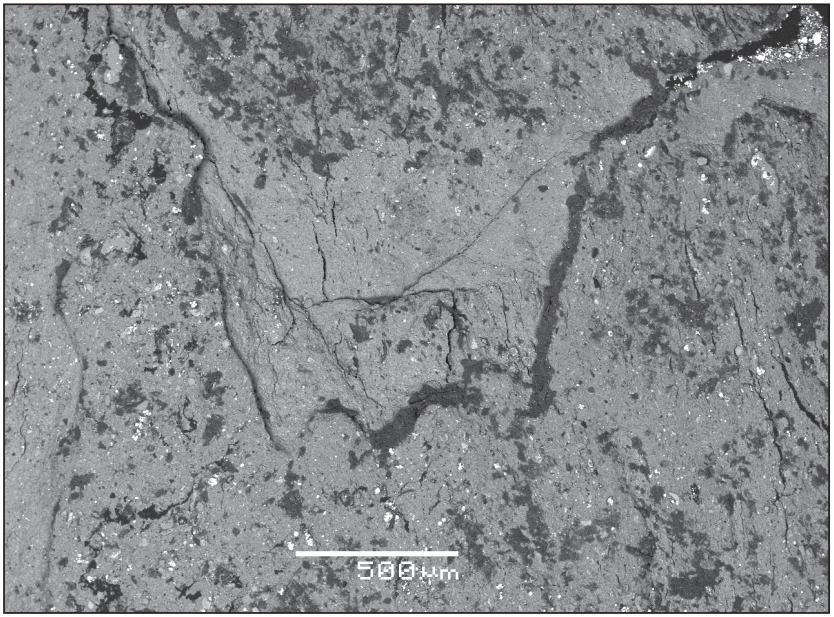

Figure 13. SEM back-scattered image showing organic matter maturation induced microfracturing in a sample from the Tau Formation in well 9/4-5 (2516 m-BSF). More examples of organic matter maturation induced microfracturing in the study area can be found in Kalani et al.(2015).

within this cluster (Fig. 12C). This shows how uncertain prediction of pore pressure in organic-rich shales and mudstones is due to the complicated interplay between various parameters influencing variations in pore pressure. Besides the level of organic maturation, the porepressure development in organic-rich, fine-grained sediments can be directly affected by the nature and progress of chemical compaction and the microfracture frequency (Vernik \& Landis, 1996; Berg \& Gangi, 1999; Osborne \& Swarbrick, 1999; Nadeau et al., 2002; Nadeau, 2011). The potential for pressure build-up may be compensated by microfracturing (Fig. 13) and the consequent primary migration of hydrocarbons toward the carrier beds. Even so, a substantial portion of the generated hydrocarbons would remain within the source rock. Geochemical data suggest that the amount of hydrocarbons expelled from the Tau Formation is only around $15 \%$ of the total generated hydrocarbons within the formation (Ritter et al., 1987; Ritter, 1988; Hermanrud et al., 1990). Matrix permeability reduction due to illitisation may increase the efficiency of hydrocarbon expulsion via overpressure and fracture creation. In turn, this may require higher levels of organic maturities. The relatively low migration efficiency of the source rocks, including those of this study, means that the formations could retain a considerable proportion of the hydrocarbons generated resulting in the formation of an overpressure.

\section{Exhumation-related unloading}

A minor increase of pore volume can cause reductions in pore pressure based on the amount of dilation rate of uplift/exhumation and permeability of the rocks (Luo \& Vasseur, 1995). Swarbrick \& Osborne (1998) have argued, however, that irreversibility of mechanical compaction as well as the poorly known rheology values of mudrocks makes the amount of dilation caused by uplift uncertain.
In addition to mechanical compaction, the strata of interest in this work were most effectively chemically compacted before the Late Cenozoic exhumation. This indicates that dilatancy of pores during uplift is probably of minor importance in the area of the Egersund Basin.

\section{Comment on petrophysical estimation of pore pressure}

Lithologically related variations of log-derived, predicted pore pressures have been mentioned earlier by Fertl (1976). The sonic, log-derived, predicted pore pressure in chemically compacted intervals and organic-rich, thermally mature successions may show both underestimation and overestimation, respectively (Fig. 4). NCT-based prediction methods rely on the prediction of pore pressure due to underconsolidation (Hottmann \& Johnson, 1965; Eaton, 1975; Bowers, 1995). However, with regard to fine-grained sediments on the Norwegian Shelf, underconsolidation is rather typical of Cenozoic intervals. The illitisation process involves volume changes with the illitisation of smectite ranging from an increase of $4.1 \%$ to a decrease of $8.4 \%$ volume based on different possible illitisation reactions (Osborne \& Swarbrick, 1999). The illitisation process results in an increase of the sonic velocity (Storvoll \& Brevik, 2008; Thyberg et al., 2010). Such an increase in Vp (i.e., decrease of sonic transit time) will likely overprint underconsolidation induced overpressure. Therefore, the predicted pore pressure may underestimate the actual pore pressure. On the other hand, the occurrence of organic matter results in a high acoustic anisotropy. Notably, a lower Vp (higher sonic transit time) is measured normal to bedding in organic-rich sediments. A pronounced deviation of the sonic data from NCT may therefore be due to organic matter rather than underconsolidation induced by overpressure. In such intervals, a modelling of organic matter maturation related volume increase may better predict hydrocarbon generation induced overpressuring. While the regular NCT-based prediction methods may show general trends of pore-pressure changes, they may not accurately predict abnormal pore pressure. Similarly, there are limitations using log data in the modelling of unloading-related overpressure (Goulty \& Ramdhan, 2011,2012 ) based on Bowers' approach (Bowers, 1995).

The fact that chemical compaction is almost independent of vertical effective stress (Bjørlykke, 1998; Bjørlykke \& Høeg, 1998) causes the bulk density and neutron porosity to be relatively independent of chemical compaction. Similarly, Hermanrud et al. (1998) showed that the bulk density and neutron porosity of hydrostatic-pressured and overpressured shale intervals in the Haltenbanken area are not niticeably different. The illitisation process, however, includes dissolution of more porous smectite and precipitation of stiffer I-S and quartz cement (Thyberg et al., 2010) which can cause a notable shift in Vp. Chemical compaction can continue in the overpressured 
zones as the elongated pores located between clay particles tend to close even at fairly low effective stress levels (Ramdhan \& Goulty, 2010, 2011; Goulty et al., 2012). In a recent study by Cicchino et al. (2015), it has been shown that large variations of porosity in mudstones from the Haltenbanken area are not a function of overpressure differences. This is reported in a chemical compactionrelated overpressured zone. The effect of stiffening on log response has a more pronounced impact on log response than the unloading related to porosity increases, and overpressure can merely partly retard an increase of $\mathrm{Vp}$ values.

\section{Conclusions}

In this study, fine-grained overpressured intervals from the Egersund Basin in the Central North Sea were analysed with regard to mineralogical composition, organic carbon content and log-derived petrophysical properties to highlight the effect of diagenetic processes on abnormal pore pressure. Results show that several parameters can affect the pore pressure inside a sedimentary layer:

1 The Cenozoic sedimentsin the Egersund Basin are currently within the mechanical compaction domain at temperatures lower than required for siliciclastic chemical diagenesis. The primary depositional parameters, especially mineralogical composition, control the pore pressure of fine-grained mudstones during mechanical compaction. Since the Cenozoic fine-grained successions are low in bulk smectite content and also contain some coarser grains of silt, the permeability is high enough to prevent overpressure build-up at shallow depths.

2 The diagenetic processes occurring at temperatures $>70^{\circ} \mathrm{C}$ (e.g., in the Sauda Formation, Zone $\boldsymbol{b}$ ) may lead to overpressure by increasing the pore fluid volume through releasing water as a by-product of illitisation of smectite, as well as volume expansion due to kerogen maturation and generation of hydrocarbon. Due to the interplay between the above-mentioned processes, discriminating between them is difficult.

3 Rock stiffness is increased by chemical diagenesis and cement precipitation and makes the physical properties (e.g., Vp) insensitive to pore-pressure changes.

4 Transformation of solid organic matter into fluid hydrocarbons involves a noticeable increase in fluid volume. Since hydrocarbon generation is possibly much faster than its dissipation through pore fluid flow in low-permeability shales, hydrocarbon generation results in pressure build-up. The pressure buildup is partly compensated by microfracturing of the source rock. However, a major portion of the gener- ated hydrocarbons would possibly not migrate out of the source rock resulting in a build-up of overpressure. This is observed particularly in the Tau Formation in the Egersund Basin area (Zone $c$ ), and can be identified as having important implications for source-rock expulsion efficiency, timing, and recovery with respect to unconventional shale oil/gas reservoirs.

5 The hydrocarbon generation induced overpressure cannot be accurately predicted petrophysically. The sharp reversal trends in the log-derived $\mathrm{Vp}$ and resistivity, which are typically used to infer NCTs, are dominated by the kerogen anisotropy and hydrocarbon content, respectively. Consequently, deviation of log data from the NCTs in organic-rich shales should not be regarded as an overpressure indicator.

Acknowledgements. This study is part of the CLIMIT (the Norwegian research program for accelerating the commercialisation of Carbon Capture and Storage (CCS) by financial stimulation of research, development and demonstration) project $\mathrm{CO}_{2} \mathrm{SEAL}$ (evaluation of the long-term sealing capabilities in the southern Norwegian sector of the North Sea for $\mathrm{CO}_{2}$ storage purposes) funded by the Norwegian Research Council (NFR) and Statoil. We also thank Dr. Maarten Aerts and Berit Løken Berg at the Department of Geosciences, University of Oslo, for technical assistance during the XRD and SEM work, respectively. Comments on an earlier version of this manuscript by Prof. Paul Nadeau and Dr. Agus Ramdhan notably led to improvements in the final version.

\section{Reference list}

Angeli, M., Faleide, J.I. \& Gabrielsen, R.H. 2013: Evaluating Seal Quality for Potential Storage Sites in the Norwegian North Sea. Energy Procedia 37, 4853-4862.

Barriol, Y., Glaser, K.S., Pop, J., Bartman, B., Corbiell, R., Eriksen, K.O., Laastad, H., Laidlaw, J., Manin, Y., Morrison, K., Sayers, C.M., Romero, M.T. \& Volokitin, Y. 2005: The Pressures of Drilling and Production. Oilfield Review, 22-41.

Berg, R.R. \& Gangi, A.F. 1999: Primary migration by oil-generation microfracturing in low-permeability source rocks: application to the Austin Chalk, Texas. American Association of Petroleum Geologists Bulletin 83, 727-756.

Bergmann, J., Friedel, P. \& Kleeberg, R. 1998: BGMN-A new fundamental parameters based Rietveld program for laboratory X-ray sources, its use in quantitative analysis and structure investigations. Commission of Powder Diffraction Newsletter, International Union of Crystallography 20, 5-8.

Bjørlykke, K. 1998: Clay mineral diagenesis in sedimentary basins: a key to the prediction of rock properties: examples from the North Sea Basin. Clay Minerals 33, 15-34.

Bjørlykke, K. \& Høeg, K. 1998: Effects of burial diagenesis on stress, compaction and fluid flow in sedimentary basins. Marine and Petroleum Geology 14, 267-276.

Boles, J.R. \& Franks, S.G. 1979: Clay diagenesis in Wilcox sandstones of southwest Texas: implications of smectite diagenesis on sandstone cementation. Journal of Sedimentary Research 49, 55-70.

Bowers, G.L. 1995: Pore Pressure Estimation from Velocity Data: Accounting for Overpressure Mechanisms Besides Undercompaction. Society of Petroleum Engineers Drilling \& Completion 10, 89-95. 
Bruce, C.H. 1984: Smectite dehydration-its relation to structural development and hydrocarbon accumulation in Northern Gulf of Mexico Basin. American Association of Petroleum Geologists Bulletin 68, 673-683.

Cicchino, A.M.P., Sargent, C., Goulty, N.R. \& Ramdhan, A.M. 2015: Regional variation in Cretaceous mudstone compaction trends across Haltenbanken, offshore mid-Norway. Petroleum Geoscience $21,17-34$.

Conin, M., Henry, P., Bourlange, S., Raimbourg, H. \& Reuschlé, T. 2011: Interpretation of porosity and LWD resistivity from the Nankai accretionary wedge in light of clay physicochemical properties: Evidence for erosion and local overpressuring. Geochemistry, Geophysics, Geosystems 12, Q0AD07.

Eaton, B.A. 1972: Graphical Method Predicts Geopressures Worldwide. World Oil 182, 51-56.

Eaton, B.A. 1975: The equation for geopressure prediction from well logs. Fall Meeting of the Society of Petroleum Engineers of AIME, 28 September-1 October, Dallas, Texas, USA.

Evans, D. 2003: The Millennium Atlas: Petroleum geology of the central and northern North Sea. CD produced by Lynx Geographic Information Systems.

Fertl, W.H. 1976: Geophysical Methods Detect and Evaluate Abnormal Formation Pressures (Chapter 3). In Fertl, W.H., Chilingarian, G.V. \& Herman, H.R. (eds.): Abnormal Formation Pressures, Developments in Petroleum Science 2, Elsevier, Amsterdam \& New York, pp. 101-116.

Fjeldskaar, W., Prestholm, E., Guargena, C. \& Gravdal, N. 1993: Isostatic and tectonic development of the Egersund Basin. In Doré, A.G., Augustson, J.H., Hermanrud, C., Stewart,

D.J. \& Sylta, Ø. (eds.): Basin modelling: Advances and applications, Norwegian Petroleum Society Special Publication 3, Elsevier, Amsterdam, pp. 549-562.

Goulty, N.R. \& Ramdhan, A.M. 2011: Limitations on Disequilibrium Compaction as a Mechanism of Overpressure Generation. 73rd European Association of Geoscientists \& Engineers Conference and Exhibition incorporating SPE EUROPEC 2011, 23 May, Vienna, Austria, F022.

Goulty, N.R. \& Ramdhan, A.M. 2012: The challenge of pore pressure estimation in diagenetically consolidated mudrocks. First Break 30, $31-36$.

Goulty, N.R., Ramdhan, A.M. \& Jones, S.J. 2012: Chemical compaction of mudrocks in the presence of overpressure. Petroleum Geoscience $18,471-479$.

Halland, E.K., Johansen, W.T. \& Riis, F. 2011: CO2 storage atlas North Sea. Norwegian Petroleum Directorate, Stavanger.

Hart, B.S., Macquaker, J.H.S. \& Taylor, K.G. 2013: Mudstone ("shale") depositional and diagenetic processes: Implications for seismic analyses of source-rock reservoirs. Interpretation 1, B7-B26.

Heasler, H.P. \& Kharitonova, N.A. 1996: Analysis of sonic well logs applied to erosion estimates in the Bighorn Basin, Wyoming. American Association of Petroleum Geologists Bulletin 80, 630-646.

Henry, P. 1997: Relationship between porosity, electrical conductivity, and cation exchange capacity in Barbados wedge sediments. Proceedings of the Ocean Drilling Program, Scientific results 156, pp. 137-149.

Hermanrud, C., Eggen, S., Jacobsen, T., Carlsen, E.M. \& Pallcscn, S. 1990: On the accuracy of modelling hydrocarbon generation and migration: the Egersund Basin oil find, Norway. Organic Geochemistry 16, 389-399.

Hermanrud, C., Wensaas, L., Teige, G.M.G., Nordgård Bolås, H.M., Hansen, S. \& Vik, E. 1998: Shale porosities from well logs on Haltenbanken (offshore mid-Norway) show no influence of overpressuring. In Law, B.E., Ulmishek, G.F. \& Slavin, V.I. (eds.): Abnormal Pressures in Hydrocarbon Environments, American Association of Petroleum Geologists Memoir 70, pp. 65-85.

Hottmann, C. \& Johnson, R. 1965: Estimation of formation pressures from log-derived shale properties. Journal of Petroleum Technology $17,717-722$
Irwin, H., Hermanrud, C., Carlsen, E., Vollset, J. \& Nordvall, I. 1993. Basin modelling of hydrocarbon charge in the Egersund basin, Norwegian North Sea, pre-and post-drilling assessments. In Doré, A.G., Augustson, J.H., Hermanrud, C., Stewart, D.J. \& Sylta, Ø. (eds.): Basin Modelling: Advances and Applications, Norwegian Petroleum Society Special Publication 3, Elsevier, Amsterdam, pp. 539-548.

Jackson, C.A.L., Chua, S.T., Bell, R.E. \& Magee, C. 2013: Structural style and early stage growth of inversion structures: 3D seismic insights from the Egersund Basin, offshore Norway. Journal of Structural Geology 46, 167-185.

Jensen, L.N. \& Schmidt, B.J. 1993: Neogene Uplift and Erosion Offshore South Norway: Magnitude and Consequences for Hydrocarbon Exploration in the Farsund Basin. In Spencer, A.M. (ed.): Generation, Accumulation and Production of Europe's Hydrocarbons III, Springer, Berlin, pp. 79-88.

Kalani, M., Jahren, J., Mondol, N.H. \& Faleide, J.I. 2015: Petrophysical implications of source rock microfracturing. International Journal of Coal Geology 143, 43-67.

Kalani, M., Jahren, J., Mondol, N.H. \& Faleide, J.I. in press: Compaction processes and rock properties in uplifted clay dominated units, - the Egersund Basin, Norwegian North Sea. Marine and Petroleum Geology.

Koochak Zadeh, M., Mondol, N.H. \& Jahren, J. 2014: Compaction and rock properties of Cenozoic mudstones in the Quadrant 15, Offshore Norway. Fourth European Association of Geoscientists \& Engineers Shale Workshop, 6-9 April, Porto, Portugal, Tu 06.

Krushin, J. 2014: Quantifying shale pore pressure by modeling the controls on compaction and porosity. Interpretation 2, SB79-SB88.

Larionov, V. 1969: Radioactivity by Well Log. Nedra, Moscow (in Russian).

Luo, X. \& Vasseur, G.U.Y. 1995: Modelling of pore pressure evolution associated with sedimentation and uplift in sedimentary basins. Basin Research 7, 35-52.

Mann, U. 1994: An integrated approach to the study of primary petroleum migration. In Parnell, J. (ed.): Geofluids: Origin, Migration and Evolution of Fluids in Sedimentary Basins, The Geological Society of London Special Publication 78, pp. 233-260.

Marcussen, Ø., Thyberg, B.I., Peltonen, C., Jahren, J., Bjørlykke, K. \& Faleide, J.I. 2009: Physical properties of Cenozoic mudstones from the northern North Sea: Impact of clay mineralogy on compaction trends. American Association of Petroleum Geologists Bulletin 93, 127-150.

Mogensen, T.E. \& Jensen, L.N. 1994: Cretaceous subsidence and inversion along the Tornquist Zone from Kattegat to the Egersund Basin. First Break 12, 211-222.

Mondol, N.H. 2009: Porosity and permeability development in mechanically compacted silt-kaolinite mixtures. 2009 Society of Exploration Geophysicists Annual Meeting, 25-30 October, Houston, Texas, USA.

Mondol, N.H., Bjørlykke, K., Jahren, J. \& Høeg, K. 2007: Experimental mechanical compaction of clay mineral aggregates-Changes in physical properties of mudstones during burial. Marine and Petroleum Geology 24, 289-311.

Mondol, N.H., Bjørlykke, K. \& Jahren, J. 2008a: Experimental compaction of clays: relationship between permeability and petrophysical properties in mudstones. Petroleum Geoscience 14,319-337.

Mondol, N.H., Fawad, M., Jahren, J. \& Bjørlykke, K. 2008b: Synthetic mudstone compaction trends and their use in pore pressure prediction. First Break 26, 43-51.

Nadeau, P. 2011: Earth's energy "Golden Zone": a synthesis from mineralogical research. Clay Minerals 46, 1-24.

Nadeau, P.H., Peacor, D.R., Yan, J. \& Hillier, S. 2002: IS precipitation in pore space as the cause of geopressuring in Mesozoic mudstones, Egersund Basin, Norwegian continental shelf. American Mineralogist 87, 1580-1589.

NPD, 2014: Norwegian Petroleum Directorate Fact Pages. 
Osborne, M.J. \& Swarbrick, R.E. 1999: Diagenesis in North Sea HPHT clastic reservoirs - consequences for porosity and overpressure prediction. Marine and Petroleum Geology 16, 337-353.

Passey, Q.R., Bohacs, K., Esch, W.L., Klimentidis, R.E. \& Sinha, S. 2010: From oil-prone source rock to gas-producing reservoir - geologic and petrophysical characterization of shale-gas reservoirs. CPS/ Society of Petroleum Engineers International Oil \& Gas Conference and Exhibition, 8-10 June, Beijing, China, SPE 131350.

Perry, E.A. \& Hower, J. 1972: Late-Stage Dehydration in Deeply Buried Pelitic Sediments. American Association of Petroleum Geologists Bulletin 56, 2013-2021.

Poelchau, H.S., Baker, D.R., Hantschel, T., Horsfield, B. \& Wygrala, B. 1997: Basin Simulation and the Design of the Conceptual Basin Model. In Welte, D., Horsfield, B. \& Baker, D. (eds.): Petroleum and Basin Evolution, Springer, Berlin, Heidelberg, pp. 3-70.

Ramdhan, A.M. \& Goulty, N.R. 2010: Overpressure-generating mechanisms in the Peciko Field, Lower Kutai Basin, Indonesia. Petroleum Geoscience 16, 367-376.

Ramdhan, A.M. \& Goulty, N.R. 2011: Overpressure and mudrock compaction in the Lower Kutai Basin, Indonesia: A radical reappraisal. American Association of Petroleum Geologists Bulletin 95, 17251744.

Ritter, U. 1988: Modelling of hydrocarbon generation patterns in the Egersund Sub-Basin, North Sea. Organic Geochemistry 13, 165-174.

Ritter, U., Leith, T.L., Griifiths, C.M. \& Sehou, L. 1987: Hydrocarbon generation and thermal evolution in parts of the Egersund Basin, Northern North Sea. In Beaumont, C. \& Tankard, A.J. (eds.): Sedimentary Basins and Basin Forming Mechanism, Canadian Society of Petroleum Geology Memoir 12, pp. 75-85.

Sayers, C., Johnson, G. \& Denyer, G. 2002: Predrill pore-pressure prediction using seismic data. Geophysics 67, 1286-1292.

Storvoll, V. \& Brevik, I. 2008: Identifying time, temperature, and mineralogical effects on chemical compaction in shales by rock physics relations. The Leading Edge 27, 750-756.

Swarbrick, R.E. \& Osborne, M.J. 1998: Mechanisms that generate abnormal pressures: An overview. In Law, B.E., Ulmishek, G.F. \& Slavin, U.I. (eds.): Abnormal pressures in hydrocarbon environments, American Association of Petroleum Geologists Memoir 70, pp. 13-34.

Swarbrick, R.E., Osborne, M.J. \& Yardley, G.S. 2002: Comparison of overpressure magnitude resulting from the main generating mechanisms. In Huffman, A.R. \& Bowers, G.L. (eds.): Pressure regimes in sedimentary basins and their prediction, American Association of Petroleum Geologists Memoir 76, pp. 1-12.

Sørensen, S. \& Tangen, O.H. 1995: Exploration trends in marginal basins from Skagerrak to Stord. In Hanslien, S. (ed.): Norwegian Petroleum Society Special Publications Volume 4, Elsevier, 97-114.

Sørensen, S., Morizot, H. \& Skottheim, S. 1992: A tectonostratigraphic analysis of the southeast Norwegian North Sea Basin. In Larsen, R.M., Brekke, H., Larsen, B.T. \& Talleraas, E. (eds.): Structural and Tectonic Modelling and its Application to Petroleum Geology, Norwegian Petroleum Society Special Publication 1, Elsevier, Amsterdam, pp. 19-42.

Terzaghi, K. 1925: Principles of soil mechanics, IV-Settlement and consolidation of clay. Engineering News-Record 95, 874-878.

Thyberg, B. \& Jahren, J. 2011: Quartz cementation in mudstones: sheetlike quartz cement from clay mineral reactions during burial. Petroleum Geoscience 17, 53-63.

Thyberg, B.I., Jordt, H., Bjørlykke, K. \& Faleide, J.I. 2000: Relationships between sequence stratigraphy, mineralogy and geochemistry in Cenozoic sediments of the northern North Sea. In Nøttvedt, A. (ed.): Dynamics of the Norwegian Margin, The Geological Society of London Special Publication 167, pp. 245-272.

Thyberg, B., Jahren, J., Winje, T., Bjørlykke, K., Faleide, J.I. \& Marcussen, Ø. 2010: Quartz cementation in Late Cretaceous mudstones, northern North Sea: Changes in rock properties due to dissolution of smectite and precipitation of micro-quartz crystals. Marine and Petroleum Geology 27, 1752-1764.
Vernik, L. \& Nur, A. 1992: Ultrasonic velocity and anisotropy of hydrocarbon source-rocks. Geophysics 57, 727-735.

Vernik, L. \& Landis, C.R. 1996: Elastic Anisotropy of Source Rocks: Implications for Hydrocarbon Generation and Primary Migration. Geophysics 80, 531-544.

Vernik, L. \& Milovac, J. 2011: Rock physics of organic shales. The Leading Edge 30, 318-323.

Yu, H. \& Hilterman, F. 2014: The effect of pressure on rock properties in the Gulf of Mexico: Comparison between compaction disequilibrium and unloading. Interpretation 2, SB1-SB15. 